medRxiv preprint doi: https://doi.org/10.1101/2021.11.09.21266103; this version posted November 9,2021 . The copyright holder for this preprint (which was not certified by peer review) is the author/funder, who has granted medRxiv a license to display the preprint in It is made available under a CC-BY-NC-ND 4.0 International license

\title{
Risk factors for burnout among couriers: A systematic review of the Chinese and English language literatures
}

Correspondence: Hua Wei, The University of Manchester, Ellen Wilkinson Building, Oxford Road, Manchester, M13 9PL, hua.wei@manchester.ac.uk

Authors: Hua Wei ${ }^{1}$, Shugang $\mathrm{Li}^{2}$, Thomas O'Toole ${ }^{1}$, Mengke $\mathrm{Yu}^{3}$, Sheng $\mathrm{Li}^{4}$, Christopher J. Armitage $^{5}$, Tarani Chandola ${ }^{6}$, Pauline Whelan ${ }^{7}$, Yan $\mathrm{Xu}^{3}$, Martie van Tongeren ${ }^{1}$

\section{Affiliations:}

1 Division of Population Health, Health Services Research \& Primary Care, School of Health Sciences, University of Manchester, Manchester, UK; 2 Department of Maternal and Children Health, School of Public Health, Capital Medical University, Beijing, China; 3 Faculty of Psychology, Beijing Normal University, Beijing, China; 4 Department of Public Health, School of Medicine, Shihezi University, Shihezi, China; 5 Division of Psychology \& Mental Health, School of Health Sciences, University of Manchester, Manchester, UK; 6 Department of Sociology, The University of Hong Kong, Hong Kong SAR China; 7 Division of Informatics, Imaging \& Data Sciences, School of Health Sciences, University of Manchester, Manchester, UK;

Word count (excluding title page, abstract, references, figures and tables): 3315

Keywords: burnout, couriers, risk factors, gig economy, China

\section{ABSTRACT}

Objectives: Courier jobs are characterised as high demand, low control with lack of support, meaning that job burnout is a serious concern. Burnout could have negative influences on safety, performance, turnover and work engagement. This paper aims to review existing evidence about the level of and risk factors for burnout among couriers.

Design: Systematic review and narrative synthesis

Primary and secondary outcome measures: Burnout, risk factors

The review followed PRISMA to search studies published in English and Chinese. English databases included MEDLINE, EMBASE, PsycINFO, Cochrane Library, Web of Science (Core Collection), Open Science Framework and Google Scholar. Chinese databases included CNKI, WANFANG data, Sino Med and CQVIP.

Results: The search yielded nine papers, of which eight studied Chinese couriers and one Malaysian. Two of them were published in English language and seven were published in Chinese. Seven studies reported moderate to high levels of burnout, such as mean scores of 2.45 on a $1-5$ scale, 4.02 on a $0-7$ scale, and 49 where the total score is between 15 and 75 . The included studies demonstrated that burnout is associated with low income, work stress, physical demands, emotional demands and organizational constraints. Some of them also measured factors that ameliorate the negative effect of work stress on burnout, such as job resources, decision latitude, social support and organizational support. Individual psychological processes, such as emotional regulation and psychological empowerment also play a role in ameliorating or exacerbating burnout. Level of burnout also varies significantly among different socio-demographic groups, such as age, income and marital status.

Conclusions: Job burnout is moderate to high among couriers, but there is a dearth of literature in the English language. Interventions to prevent or reduce burnout are currently lacking but could include increasing job autonomy and offering more organizational support. 
medRxiv preprint doi: https://doi.org/10.1101/2021.11.09.21266103; this version posted November 9,2021 . The copyright holder for this preprint (which was not certified by peer review) is the author/funder, who has granted medRxiv a license to display the preprint in It is made available under a CC-BY-NC-ND 4.0 International license .

\section{Strengths and limitations of this study}

- Given the importance of China in global e-commerce, comprehensive search strategies were employed to review publications in both English and Chinese languages

- Outcome measures investigated have been clearly defined and referenced.

- This review followed the Preferred Reporting Items for Systematic Reviews and MetaAnalyses reporting guideline.

- However, due to the heterogeneity of included studies, it was not meaningful to perform meta-analysis.

\section{BACKGROUND}

The COVID-19 pandemic has highlighted the essential roles of healthcare workers and couriers in maintaining public health and keeping economies running during lockdowns. It is also known that occupations such as healthcare and last mile logistics are physically and psychologically demanding, a known factor for job burnout.[1, 2] However, while research about healthcare workers' burnout has supplied good quality evidence for intervention development,[3-5] understanding about the level of burnout and relevant risk factors among couriers is lacking. The aim of the present research is to review systematically the literature on risk factors and burnout among couriers with a view to identifying targets for intervention.

The burnout issue among couriers has come to our attention not just because of the surged demand for home deliveries during the COVID-19 pandemic, but also the rapid expansion of global e-commerce in the last a few decades.[6] China has become the global leader of ecommerce and the fastest growing region. In 2019, China's online retail sales reached $\$ 1,625.00$ billion, a figure that grew by $16.5 \%$ from 2018 (MofCom.gov.cn). The phenomenal growth has triggered a large amount of research published in Chinese. The importance and resilience of the sector is supported by a large and growing work population, parcel and takeaway couriers who connect the last mile of the logistics. However, current working practices may present multiple mental health risks.[7] A recent road safety study from China revealed that $76.5 \%$ of interviewed couriers $(n=480)$ had been involved in a traffic crash at least once, while the average length of staying in this occupation was only about 1.5 years.[8] Research about overwork among Chinese takeaway couriers also found that $41.74 \%$ respondents $(\mathrm{n}=1114)$ were at high risk of overworking (danger zone), 35.91\% were at very high risk of overworking (acute danger zone) and only $7.9 \%$ were considered risk free (safe zone).[9] The Chinese language literature may therefore be a key area to search for relevant research on burnout in couriers and will go some way to extending the reach of previous systematic reviews of burnout, which to date have focused on English language databases, effectively ignoring vast sections of the global economy.

Even in European countries, such as the UK where health and safety standards are deemed high, $42 \%$ of surveyed couriers and taxi drivers $(n=231)$ said they had been involved in a collision where vehicle had been damaged and $10 \%$ said that someone had been injured, usually themselves.[10] Parcel and food delivery is an essential part of the gig economy, where workers are categorised as self-employed and the platforms do not provide the traditional employer responsibilities, such as health, safety and other employee benefits. While this mode of working has the benefit of flexibility, analysis of large scale survey data in North America has shed additional light on the relationship between gig workers' socio-economic status and work 
medRxiv preprint doi: https://doi.org/10.1101/2021.11.09.21266103; this version posted November 9,2021 . The copyright holder for this preprint (which was not certified by peer review) is the author/funder, who has granted medRxiv a license to display the preprint in

It is made available under a CC-BY-NC-ND 4.0 International license .

stress, that is the dependency on platforms (ie as the main job and only source of income) and financial strain exacerbate the mental health penalties associated with platform work.[11] These studies, although they do not focus directly on couriers' burnout, depict a stressful work environment. Multiple drivers of burnout are at work, including excessive work load and time pressure, low job control, low safety standard, lack of organizational support and other socioeconomic factors. Therefore, it is important that we have a clear understanding about the situation, so that relevant research can be developed to evaluate and mitigate high risks. This review aims answer the questions by reviewing evidence from the Chinese and English language literatures. Our review questions are:

Q1 What is the level of job burnout among couriers?

Q2 What are the main risk factors of job burnout among couriers?

There are several popular definitions of burnout[12] and this review adopts the one summarized by Schaufeli and Greenglass[13]: burnout is the state of physical, emotional and mental exhaustion that results from long-term involvement in work situations that are emotionally demanding. It has three dimensions: emotional exhaustion, depersonalization, and reduced personal accomplishment.[14] Please note the "depersonalization" dimension is also named "cynicism" or "disengagement" in some literature. They appeared to be referring to the same construct, hence this paper adopt these dimension names interchangeably. The similar applies to the "reduced personal accomplishment" dimension that is often named "low professional efficacy" or "low sense of achievement".

\section{METHOD}

\section{Search strategy}

The initial searches were completed in April 2021, with additional searches carried out in September 2021 to catch the latest publications.

We searched the following electronic databases for English literature:

- MEDLINE, EMBASE, PsycINFO and the Cochrane Library (from their respective inception dates to the current date) using OVID platform.

- Web of Science (Core Collection)

- Pre-print database: Open Science Framework

- Grey Literature database: Google Scholar

We also searched the following Chinese electronic databases for Chinese literature:

- CNKI (http://new.oversea.cnki.net/index/).

- WANFANG data

- Sino Med

- VIP (http://www.cqvip.com/)

For search terms on OVID, we started with Exp Burnout to catch as much as possible relevant terms, in addition, we used (burnout OR stress OR job strain OR fatigue OR exhaustion OR tired OR tiredness OR tiring OR weariness OR worn out) to include possibly related terms in social and health sciences. For the occupation, we used (courier* or deliverym*n or delivery worker* or delivery driver* or takeaway delivery) to catch all relevant population in focus. At the end, we used (work OR occupational OR job) to limit results to studies that are workrelated. A full search strategy on all databases is available as supplemental material.

We also hand searched the reference lists of all the included studies, and of some excluded studies. We have reviewed peer-reviewed papers and postgraduate theses that are published in 
medRxiv preprint doi: https://doi.org/10.1101/2021.11.09.21266103; this version posted November 9,2021 . The copyright holder for this preprint (which was not certified by peer review) is the author/funder, who has granted medRxiv a license to display the preprint in

It is made available under a CC-BY-NC-ND 4.0 International license .

English or Chinese, with the full text available. No restriction on publication dates were applied.

\section{Inclusion/Exclusion criteria}

Reviews, RCT, CRT, observational and qualitative studies are all eligible.

Inclusion criteria: Studies assessing levels of occupational burnout in a population of couriers/delivery workers or reporting associated risk factors.

Exclusion criteria: Studies not focussing on work-related mental ill health or not in a sample of delivery workers or couriers; Conference abstracts; Commentaries; Studies not in English or Chinese language.

Couriers including parcel/goods couriers and takeaway food couriers who conduct the "last mile" deliveries will be the focus of the review. Hence, studies about postmen, public transport drivers and long-haul truck or lorry drivers were excluded.

Most studies used Maslach Burnout Inventory (MBI) to measure burnout. Due to the variation in relation to cut-off points of burnout in existing literature, we generally considered scores above the middle point as an indication of high burnout.

\section{Patient and Public Involvement}

Patient consent for publication is not required.

\section{Review process}

We followed a review process adapted from the Preferred Reporting Items for Systematic Reviews and Meta-Analyses[15] (see Figure 1 PRISMA diagram below). A review protocol was pre-published on PROSPERO (ID: CRD42021247644). It was deemed meta-analysis or subgroup analysis was not meaningful due to the varied reporting standards and measurement tools used in the included studies, and qualitative synthesis was the most appropriate method. Five reviewers (HW, SGL, TO, MKY and SL) formed two teams to carry out systematic reviews in Chinese and English. SGL, MKY and SL were responsible for Chinese review and HW and TO English. Both teams went through the same steps, including searching the databases, screening the results, data extraction and quality assessment. The protocol was reviewed by and discussed among all the co-authors, with feedback actively taken into account to ensure quality of the process. HW and SGL cross checked both languages at each steps to maintain consistent standard. When both reviews were completed, HW translated data extracted from the Chinese review into English. The abstracts of all included Chinese studies were also translated into English by HW to enable discussions among all co-authors.

For the step of title/abstract screening, we used a standardised title and abstract form. The form was developed in English by all five reviewers. Each team conducted a pilot exercise with the review team screening the same 10 abstracts to calibrate. Any conflicts were discussed and if disagreement remained, we would refer to the review team for further discussion until consensus was reached. Two reviewers of each team then screened the remaining abstracts independently with conflict resolution through discussion and referral to a third reviewer if necessary.

For full-text review, we used a standardised full text form. The form was developed in English by all five reviewers. Each team then conducted a pilot exercise with the same five articles reviewed by the review team to calibrate and test the form, following the same conflicts resolution process as depicted above. Two reviewers of each team then reviewed all full text 
medRxiv preprint doi: https://doi.org/10.1101/2021.11.09.21266103; this version posted November 9, 2021. The copyright holder for this preprint (which was not certified by peer review) is the author/funder, who has granted medRxiv a license to display the preprint in It is made available under a CC-BY-NC-ND 4.0 International license

articles independently with conflict resolution through discussion and referral to a third reviewer if necessary.

During data extraction, in each team, two reviewers independently extracted data using a piloted form. Again the form was developed in English by all five reviewers. Any discrepancies were checked, discussed and resolved. The same process was followed for risk of bias assessments. A version of the Newcastle Ottawa Scale (NOS) that was adapted for crosssectional surveys were used for quality assessment.[16]

We will present a narrative synthesis of the data to answer the research questions. Tables were produced to highlight key findings based upon the research questions and outcomes of interest.

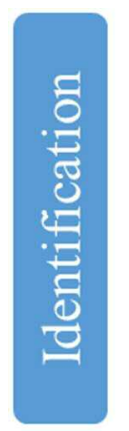

$$
\begin{aligned}
& \begin{array}{c}
\text { English Language Databases } \\
(\mathrm{n}=509) \text { : }
\end{array} \\
& \text { - }(\mathrm{n}=13) \text { Google Scholar } \\
& \text { - }(\mathrm{n}=24) \text { OVID } \\
& \text { - }(\mathrm{n}=191) \text { Web of Science } \\
& \text { - }(\mathrm{n}=281) \text { Open Science } \\
& \text { Framework }
\end{aligned}
$$

Chinese Language Databases $(n=201)$ :

- $(\mathrm{n}=41)$ CNKI

- $(\mathrm{n}=10)$ VIP

- $(\mathrm{n}=147)$ WANFANG

- $(n=3)$ SinoMed
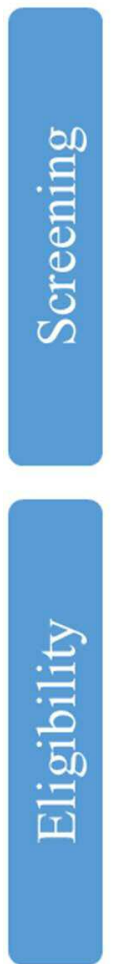

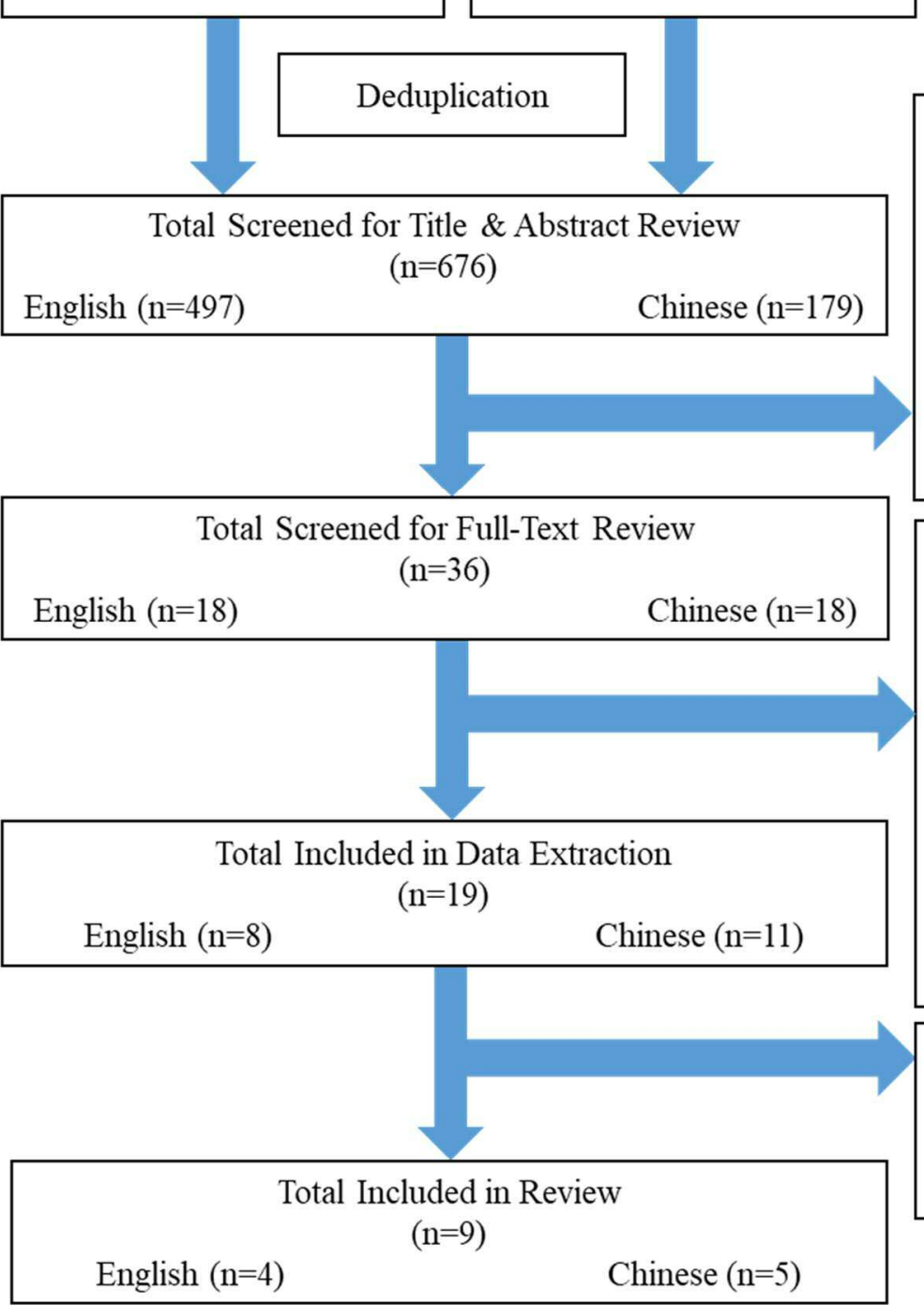

Total Excluded After Title and Abstract Review $(\mathrm{n}=640)$

Reasons:

- $(\mathrm{n}=419)$ Irrelevant

(n=27) Abstract Not Available in Eng or Chi

(n=146) Wrong Population

- (n=25) Wrong Outcome

- $(n=4)$ Wrong Exposure

- $(n=18)$ Literature Review

- $(n=1)$ Conference proceeding

Total Excluded after Full-Text Review

Reasons:

- $(n=2)$ Road Safety Outcome

- $(n=3)$ Duplicate across

Databases

- $(n=1)$ Text Not Available in Eng or Chi

- $(n=2)$ Wrong/Limited Population

- $(\mathrm{n}=1)$ Conference Proceeding

- $(\mathrm{n}=1)$ Dissertation Abstract

(n=7) Limited Outcome Measures

Total Excluded after Data

Extraction $(\mathrm{n}=10)$

Reason:

- $(n=10)$ No Burnout Results Presented 
medRxiv preprint doi: https://doi.org/10.1101/2021.11.09.21266103; this version posted November $9,2021$. The copyright holder for this preprint (which was not certified by peer review) is the author/funder, who has granted medRxiv a license to display the preprint in It is made available under a CC-BY-NC-ND 4.0 International license .

Figure 1 PRISMA diagram

\section{RESULTS}

\section{Search results}

Databases searches returned 676 results after deduplication, 497 in English and 179 in Chinese. Following title and abstract screening 36 papers were included for full-text review, after which 17 papers were further excluded, leaving 19 papers for data extraction. During data extraction a further 10 papers were excluded as they did not report burnout as an outcome of interest. At the end 9 were included for reporting and quality assessment. All included studies are crosssectional surveys. Figure 1 illustrates the number of studies excluded and reasons of exclusion at each stage.

\section{Study characteristics}

Table 1 describes the characteristics of studies included in this review from both Chinese and English language searches.

Across databases, eight out of nine included studies were from China, with one coming from Malaysia. Two were published in English and seven were in Chinese. All included studies are small to mid-sized cross-sectional surveys $(n=105-1,425$, Mean=412). Samples were primarily male ( $\sim 23 \%$ female on average), with the most frequent age bands reported being $\sim 20-40$, one study did not report age or sex/gender statistics.

Table 1 Study characteristics

\begin{tabular}{|l|l|l|l|l|l|l|l|}
\hline Reference & Country & Language & $\begin{array}{l}\text { Study } \\
\text { type }\end{array}$ & $\begin{array}{l}\text { Popula } \\
\text { tion }\end{array}$ & $\begin{array}{l}\text { Sample } \\
\text { size }\end{array}$ & Age (Mean) & $\begin{array}{l}\text { \% } \\
\text { Female }\end{array}$ \\
\hline $\begin{array}{l}\text { Cheng et } \\
\text { al, } \\
\text { 2020[17] }\end{array}$ & China & English & $\begin{array}{l}\text { Cross- } \\
\text { sectional }\end{array}$ & Parcel & 220 & $\begin{array}{l}30.9 \% \text { in the } \\
26-30 \text { band }\end{array}$ & $14 \%$ \\
\hline $\begin{array}{l}\text { Yoon et } \\
\text { al, } \\
\text { 2021[18] }\end{array}$ & Malaysia & English & $\begin{array}{l}\text { Cross- } \\
\text { sectional }\end{array}$ & Parcel & 350 & $\begin{array}{l}50 \% \text { in the } \\
21-40 \text { band }\end{array}$ & $10 \%$ \\
\hline $\begin{array}{l}\text { Xu et al, } \\
2020[19]\end{array}$ & China & Chinese & $\begin{array}{l}\text { Cross- } \\
\text { sectional }\end{array}$ & Food & 160 & $\begin{array}{l}74.99 \% \text { in 20- } \\
40\end{array}$ & $25 \%$ \\
\hline $\begin{array}{l}\text { Wang et } \\
\text { al, } \\
2015[20]\end{array}$ & China & Chinese & $\begin{array}{l}\text { Cross- } \\
\text { sectional }\end{array}$ & Parcel & 686 & NR & NR \\
\hline $\begin{array}{l}\text { Xiao, } \\
2019[21]\end{array}$ & China & Chinese & $\begin{array}{l}\text { Cross- } \\
\text { sectional }\end{array}$ & Mixed & 1425 & $\begin{array}{l}18-49,92.2 \% \\
<42\end{array}$ & $8 \%$ \\
\hline $\begin{array}{l}\text { Zhao, } \\
2009[22]\end{array}$ & China & Chinese & $\begin{array}{l}\text { Cross- } \\
\text { sectional }\end{array}$ & Parcel & 159 & $\begin{array}{l}20-50,61 \% \text { in } \\
20-25 \text { band }\end{array}$ & $41 \%$ \\
\hline $\begin{array}{l}\text { Hu, } \\
2016[23]\end{array}$ & China & Chinese & $\begin{array}{l}\text { Cross- } \\
\text { sectional }\end{array}$ & Parcel & 276 & $\begin{array}{l}20-46,80.8 \% \\
\text { in 20-30 band }\end{array}$ & $21 \%$ \\
\hline $\begin{array}{l}\text { Zhao, } \\
2020[24]\end{array}$ & China & Chinese & $\begin{array}{l}\text { Cross- } \\
\text { sectional }\end{array}$ & Parcel & 105 & $\begin{array}{l}82.9 \% \text { is 21- } \\
40 \text { age ban }\end{array}$ & $36 \%$ \\
\hline $\begin{array}{l}\text { Wu, } \\
2017[25]\end{array}$ & China & Chinese & $\begin{array}{l}\text { Cross- } \\
\text { sectional }\end{array}$ & Parcel & 325 & $\begin{array}{l}89.7 \% \text { in 20- } \\
40 \text { age band }\end{array}$ & $30 \%$ \\
\hline Abrann
\end{tabular}

Abbreviations: NR $=$ Not Reported. 
medRxiv preprint doi: https://doi.org/10.1101/2021.11.09.21266103; this version posted November 9,2021 . The copyright holder for this preprint (which was not certified by peer review) is the author/funder, who has granted medRxiv a license to display the preprint in

It is made available under a CC-BY-NC-ND 4.0 International license .

\section{Quality assessment}

Table 2 shows the results of various quality assessments carried out on the included studies, using the Newcastle-Ottawa adapted cross-sectional (NOS cross-sectional). Across studies, quality ranges from $3 / 10$ to $7 / 10$. The NOS adapted scale does not provide further interpretation of the scores. In this paper we arbitrarily attributed 1-4 to low quality, 5-7 to moderate quality and 8-10 to high quality.

Table 2 Quality assessment of the included studies

\begin{tabular}{|llll|}
\hline Reference & Quality assessment tool & Score & Quality \\
\hline $\begin{array}{l}\text { Cheng et al, } \\
\text { 2020[17] }\end{array}$ & NOS Cross-Sectional & $4 / 10$ & Low \\
$\begin{array}{l}\text { Yoon et al, } \\
\text { 2021[18] }\end{array}$ & NOS Cross-Sectional & $5 / 10$ & Moderate \\
Xu et al, 2020[19] & NOS Cross-Sectional & $4 / 10$ & Low \\
Wang et al, & NOS Cross-Sectional & $5 / 10$ & Moderate \\
2015[20] & NOS Cross-Sectional & $6 / 10$ & Moderate \\
Xiao, 2019[21] & NOS Cross-Sectional & $4 / 10$ & Low \\
$\mathrm{Zhao,} \mathrm{2009[22]}$ & NOS Cross-Sectional & $7 / 10$ & Moderate \\
$\mathrm{Hu}, 2016[23]$ & NOS Cross-Sectional & $3 / 10$ & Low \\
$\mathrm{Zhao}, 2020[24]$ & NOS Cross-Sectional & $7 / 10$ & Moderate \\
$\mathrm{Wu}, 2017[25]$ & &
\end{tabular}

Abbreviations: NOS = Newcastle Ottawa Scale;

\section{Burnout among couriers}

All included studies used a version of Maslach Burnout Inventory (MBI), or a subscale of MBI, or when scale was unspecified, the dimensions appeared to be consistent with MBI. However, language, reporting method and scale used varied significantly. In addition, most included studies did not determine cut-off points, nor reported percentages of participants fall within the different standards. Since the original MBI manual suggested cut-off points were 27 out of 54 as high in emotional exhaustion, 13 out 30 as high in depersonalisation and 21 out 48 as high in professional efficacy,[26] we then generally considered results above middle point of the scale as high burnout. The only study that specified a clinical cut-off point used a 15-item Chinese version MBI using Likert scale 1-5 and hence a total maximum score should be 75 . They defined any score $\leq 44$ as low level of burnout, $45<$ score $\leq 74$ as high and 75 as severe.[24] They found nearly half of the respondents suffered a high level of burnout, 48.57\% 45-74 $(n=105)$.

Most of the included studies reported mean scores that were either near or above the middle point of the scale, indicating moderate to high burnout in this population. For example, Yoon et al [18] used a MBI-GS that was translated and validated in Bahasa Malaysia with 16 items and a four-point frequency scale from 1 (never) to 4 (always). They reported a mean score at 2.45, which indicates high level of burnout. Xiao [21] and $\mathrm{Hu}$ [23] both used Chinese version of MBI translated and validated by Li and Shi [27], but Xiao used a 0-7 scale whilst Hu used a 1-5 scale. In terms of reporting, Xiao reported a mean score of $4.02 \pm 0.85$, which indicates high level of burnout on a 0-7 scale. Hu reported mean scores of each subscales: Emotional exhaustion: $3.3210 \pm 0.72783$, Disengagement: $2.9973 \pm 0.70436$, and Low professional efficacy: $3.1319 \pm 0.58961$. On a 1-5 scale, these scores indicate high level of burnout especially 
medRxiv preprint doi: https://doi.org/10.1101/2021.11.09.21266103; this version posted November 9, 2021. The copyright holder for this preprint (which was not certified by peer review) is the author/funder, who has granted medRxiv a license to display the preprint in

It is made available under a CC-BY-NC-ND 4.0 International license .

in the emotional exhaustion and low professional efficacy dimensions. $\mathrm{Wu}[25]$ conducted exploratory factor analysis when combined MBI with occupational stress and organizational support scales. They subsequently reduced it to 13 items and reported fairly high level of burnout among 325 respondents from confirmation factor analysis stage (Emotional exhaustion 3.7947, Depersonalisation 3.7272, Low professional efficacy 3.4997, calculated averages as the paper reported mean scores by gender). Two studies reported mean of total scores of each subscale[19] or the total mean score of the entire measurement.[22] Table 3 describes them in details. Two studies did not report the scores.[17, 20]

Table 3 Burnout among couriers

\begin{tabular}{|c|c|c|c|c|}
\hline Reference & $\begin{array}{l}\text { Parcel } \\
\text { or } \\
\text { food }\end{array}$ & Burnout & $\begin{array}{l}\text { Score (rounded to } \\
\text { two decimals) }\end{array}$ & $\begin{array}{l}\text { Cut-off for } \\
\text { high level or } \\
\text { Middle point }\end{array}$ \\
\hline $\begin{array}{l}\text { Cheng et } \\
\text { al, } \\
2020[17]\end{array}$ & Parcel & $\begin{array}{l}\text { MBI (EE dimension, modified } \\
\text { Chinese version, } 6 \text { items) }\end{array}$ & Not reported (NR) & \\
\hline $\begin{array}{l}\text { Yoon et } \\
\text { al, } \\
2021[18]\end{array}$ & Parcel & $\begin{array}{l}\text { MBI-GS, Bahasa Malaysia } \\
\text { version, } 16 \text { items, four-point } \\
\text { frequency scale } 1 \text { (never) to } 4 \\
\text { (always) }\end{array}$ & $2.45 \pm 0.65$ & 2.5 \\
\hline $\begin{array}{l}\text { Xu et al, } \\
2020[19]\end{array}$ & Food & $\begin{array}{l}\text { MBI, modified Chinese } \\
\text { version, } 12 \text { items (EE 4, CD 4, } \\
\text { LSA 4) (Likert 1-5) }\end{array}$ & $\begin{array}{l}\text { EE: } 10.78 \pm 2.56 \\
\text { CD: } 10.50 \pm 2.39 \\
\text { LSA: } 10.98 \pm 2.46\end{array}$ & $\begin{array}{l}12 \\
12 \\
12\end{array}$ \\
\hline $\begin{array}{l}\text { Wang et } \\
\text { al, } \\
2015[20]\end{array}$ & Parcel & $\begin{array}{l}\text { MBI, modified Chinese } \\
\text { version, } 14 \text { items (Likert 1-5) }\end{array}$ & NR & \\
\hline $\begin{array}{l}\text { Xiao, } \\
2019[21]\end{array}$ & Mixed & $\begin{array}{l}\text { Chinese MBI-GS -Li, } 15 \\
\text { items (Likert 0-7) }\end{array}$ & $4.02 \pm 0.85$ & 4 \\
\hline $\begin{array}{l}\text { Zhao, } \\
\text { 2009[22] }\end{array}$ & Parcel & $\begin{array}{l}\text { Burnout scale with } 3 \\
\text { dimensions: EE, CD, LSA } \\
\text { (name of scale unspecified) }\end{array}$ & $49.81 \pm 5.98$ & NR \\
\hline $\begin{array}{l}\mathrm{Hu}, \\
2016[23]\end{array}$ & Parcel & $\begin{array}{l}\text { Chinese MBI -Li, } 15 \text { items } \\
\text { (EE 5, CD 4, LPE 6) (Likert 1- } \\
\text { 5) }\end{array}$ & $\begin{array}{l}\text { EE: } 3.32 \pm 0.73 \\
\text { CD: } 3.00 \pm 0.70 \\
\text { LPE } 3.13 \pm 0.59\end{array}$ & $\begin{array}{l}3 \\
3 \\
3\end{array}$ \\
\hline $\begin{array}{l}\text { Zhao, } \\
2020[24]\end{array}$ & Parcel & $\begin{array}{l}\text { Chinese MBI -Li, } 15 \text { items } \\
\text { (Likert } 1-5)(<44 \text { low, } 45-74 \\
\text { high, } \geq 75 \text { severe })\end{array}$ & $\begin{array}{l}\text { Low: } 51.43 \%<44 ; \\
\text { High: } 48.57 \% \quad 45- \\
74 \text {; Severe: } 0 \% 75\end{array}$ & 45 \\
\hline $\begin{array}{l}\text { Wu, } \\
2017[25]\end{array}$ & Parcel & $\begin{array}{l}\text { Reduced Chinese MBI, } 13 \\
\text { items (EE 5, CD 4, LSA 4) } \\
\text { (Likert 1-5) }\end{array}$ & $\begin{array}{l}\text { EE: } 3.79 \\
\text { CD: } 3.73 \\
\text { LSA: } 3.50\end{array}$ & $\begin{array}{l}3 \\
3 \\
3\end{array}$ \\
\hline
\end{tabular}

Abbreviations: NR: Not reported, MBI: Maslach Burnout Inventory, EE: Emotional Exhaustion, CD: Cynicism/Depersonalisation, LSA: Low sense of achievement, LPE: Low professional efficacy

\section{Main factors of burnout}

All included studies reported one or more risk or protective factors for job burnout among couriers (see details in Table 4), with five of them reported in both categories. The relationships between the factors and burnout were established using statistical methods such as Correlation Coefficient (CC), structural equation modelling (SEM), or standardized coefficient (SC). 
medRxiv preprint doi: https://doi.org/10.1101/2021.11.09.21266103; this version posted November 9, 2021. The copyright holder for this preprint (which was not certified by peer review) is the author/funder, who has granted medRxiv a license to display the preprint in

It is made available under a CC-BY-NC-ND 4.0 International license .

Among the exacerbating factors, four studies analysed the relationship between occupational stress and burnout -- one found no significant association,[19] another found 70\% of the participants selected it as main factors of burnout (measured by long hours, heavy workload, safety concerns), and two found significant correlations between occupational stress and job burnout.[20, 25] Other reported exacerbating factors included physical job demands,[18] customer behaviour,[17, 24] low income, career prospect concerns and organizational constraints.[22]. One dimension of Emotional Regulation (Expressive Suppression) was reported positively correlated with job burnout and two subscales (emotional exhaustion and disengagement).[23]

Among the ameliorating factors, perceived organizational support were reported by four studies.[17, 20, 23, 25] Another dimension of Emotional Regulation (Cognitive Reappraisal) was negatively correlated with burnout.[23] Other ameliorating factors included psychological empowerment,[21] job resources, social support and decision latitude.[18]

Table 4 Risk and protective factors for burnout

\begin{tabular}{|c|c|c|c|c|}
\hline $\begin{array}{l}\text { Catego } \\
\text { ry }\end{array}$ & Factors & $\begin{array}{l}\text { Referen } \\
\text { ce }\end{array}$ & $\begin{array}{l}\text { Statis } \\
\text { tical } \\
\text { meth } \\
\text { od }\end{array}$ & Results (rounded to two decimals) \\
\hline \multirow{9}{*}{$\begin{array}{l}\text { Exacer } \\
\text { bating } \\
\text { factors }\end{array}$} & \multirow{4}{*}{$\begin{array}{l}\text { Occupati } \\
\text { onal } \\
\text { Stress }\end{array}$} & $\begin{array}{l}\mathrm{Xu} \\
2020[19]\end{array}$ & NR & $\begin{array}{l}\text { Association between OS and job burnout among } \\
\text { couriers were not significant (data not reported) }\end{array}$ \\
\hline & & $\begin{array}{l}\text { Wang et } \\
\text { al, } \\
2015[20]\end{array}$ & $\begin{array}{l}\text { Pears } \\
\text { on CC }\end{array}$ & $\begin{array}{l}\text { OS is significantly correlated with job burnout } \\
(\mathrm{r}=0.68, \mathrm{p}<0.01) \text {, and its three dimensions (EE } \\
0.93, \mathrm{CD} 0.85 \text {, LPE } 0.90, \mathrm{p}<0.01)\end{array}$ \\
\hline & & $\begin{array}{l}\text { Zhao, } \\
2020[24]\end{array}$ & $\begin{array}{l}\text { Descri } \\
\text { ptive }\end{array}$ & $\begin{array}{l}70.0 \% \text { participants selected OS as a main factor } \\
\text { of burnout (long hours, heavy workload, safety } \\
\text { concerns) }\end{array}$ \\
\hline & & $\begin{array}{l}\mathrm{Wu}, \\
2017[25]\end{array}$ & $\mathrm{CC}$ & $\begin{array}{l}\text { Work stress is positively correlated with EE, CD } \\
\text { and LPE: } r=0.48,0.52 \text { and } 0.35 \text { respectively, } \\
p<.001\end{array}$ \\
\hline & $\begin{array}{l}\text { Job } \\
\text { demand }\end{array}$ & $\begin{array}{l}\text { Yoon et } \\
\text { al, } \\
2021[18]\end{array}$ & $\begin{array}{l}\text { CC } \\
\text { CB- } \\
\text { SEM }\end{array}$ & $\begin{array}{l}\text { Job demand is correlated with job burnout } r=0.53 \text {, } \\
\mathrm{p}<0.01 \text {; } \\
\text { The result of the structural paths shows that higher job } \\
\text { demands have increased burnout }(\beta=0.52, p<0.00) \text {. } \\
\text { However, only one of the job demands' dimensions- } \\
\text { physical demands - has created a positive effect on } \\
\text { burnout }(\beta=0.50, p<0.00) \text {. }\end{array}$ \\
\hline & \multirow[t]{2}{*}{$\begin{array}{l}\text { Clients/ } \\
\text { Custome } \\
\text { rs }\end{array}$} & $\begin{array}{l}\text { Cheng et } \\
\text { al, } \\
2020[17]\end{array}$ & SEM & $\begin{array}{l}\text { Improper customer interaction has a significant } \\
\text { positive effect on emotional exhaustion }(\beta=0.61 \text {, } \\
\text { T-value }=9.38)\end{array}$ \\
\hline & & $\begin{array}{l}\text { Zhao, } \\
2020[24]\end{array}$ & $\begin{array}{l}\text { Descri } \\
\text { ptive }\end{array}$ & $\begin{array}{l}51.4 \% \text { participants selected customer } \\
\text { relationships as a main factor of burnout }\end{array}$ \\
\hline & ER -ES & $\begin{array}{l}\mathrm{Hu}, \\
2016[23]\end{array}$ & $\begin{array}{l}\text { Pears } \\
\text { on CC }\end{array}$ & $\begin{array}{l}\text { ER-ES is positively correlated with job burnout, } \\
\mathrm{EE} \text { and } \mathrm{CD}, \mathrm{r}=0.40,0.56 \text { and } 0.43, \mathrm{p}<0.01\end{array}$ \\
\hline & $\begin{array}{l}\text { Low } \\
\text { income }\end{array}$ & $\begin{array}{l}\text { Zhao, } \\
2020[24]\end{array}$ & $\begin{array}{l}\text { Descri } \\
\text { ptive }\end{array}$ & $\begin{array}{l}92.4 \% \text { participants selected low income as a main } \\
\text { factor of burnout }\end{array}$ \\
\hline
\end{tabular}


medRxiv preprint doi: https://doi.org/10.1101/2021.11.09.21266103; this version posted November 9, 2021. The copyright holder for this preprint (which was not certified by peer review) is the author/funder, who has granted medRxiv a license to display the preprint in

It is made available under a CC-BY-NC-ND 4.0 International license .

\begin{tabular}{|c|c|c|c|c|}
\hline & $\begin{array}{l}\text { Career } \\
\text { prospect } \\
\text { concerns }\end{array}$ & $\begin{array}{l}\text { Zhao, } \\
2020[24]\end{array}$ & $\begin{array}{l}\text { Descri } \\
\text { ptive }\end{array}$ & $\begin{array}{l}37.1 \% \text { participants selected Career prospect } \\
\text { concerns as a main factor of burnout }\end{array}$ \\
\hline & $\begin{array}{l}\text { Organiza } \\
\text { tional } \\
\text { constrain } \\
\text { ts }\end{array}$ & $\begin{array}{l}\text { Zhao, } \\
2009[22]\end{array}$ & $\mathrm{CC}$ & $\begin{array}{l}\text { Organizational constraints is positively } \\
\text { correlated with burnout, } \mathrm{r}=0.54, \mathrm{p}<0.01\end{array}$ \\
\hline $\begin{array}{l}\text { Amelio } \\
\text { rating }\end{array}$ & $\mathrm{PE}$ & $\begin{array}{l}\text { Xiao, } \\
2019[21]\end{array}$ & $\mathrm{CC}$ & $\begin{array}{l}\text { PE is negatively correlated with burnout } r=-0.39 \text {, } \\
p<0.01\end{array}$ \\
\hline & ER-CR & $\begin{array}{l}\mathrm{Hu}, \\
2016[23]\end{array}$ & $\begin{array}{l}\text { Pears } \\
\text { on CC }\end{array}$ & $\begin{array}{l}\text { ER-CR is negatively correlated with burnout, } r=- \\
0.14(p<0.05)\end{array}$ \\
\hline & $\begin{array}{l}\text { Job } \\
\text { resources }\end{array}$ & $\begin{array}{l}\text { Yoon et } \\
\text { al, } \\
2021[18]\end{array}$ & $\begin{array}{l}\text { CB- } \\
\text { SEM, } \\
\text { SPC }\end{array}$ & $\begin{array}{l}\text { Job resources moderate the effect of job demands } \\
\text { on burnout significantly: } \beta=-0.30, p<0.000\end{array}$ \\
\hline & $\begin{array}{l}\text { Social } \\
\text { support }\end{array}$ & $\begin{array}{l}\text { Yoon et } \\
\text { al, } 2021\end{array}$ & $\begin{array}{l}\text { CB- } \\
\text { SEM, } \\
\text { SPC }\end{array}$ & $\begin{array}{l}\text { Social support moderate the effect of physical } \\
\text { and psychological job demands on burnout: } \beta=- \\
0.27, p<0.000, \beta=-0.33, p<0.000\end{array}$ \\
\hline & $\begin{array}{l}\text { Decision } \\
\text { latitude }\end{array}$ & $\begin{array}{l}\text { Yoon et } \\
\text { al, } 2021\end{array}$ & $\begin{array}{l}\text { CB- } \\
\text { SEM, } \\
\text { SPC }\end{array}$ & $\begin{array}{l}\text { Decision latitude moderate the effect of physical } \\
\text { and psychological job demands on burnout: } \beta=- \\
0.26, p<0.000, \beta=-0.28, p<0.000\end{array}$ \\
\hline & $\begin{array}{l}\text { Perceive } \\
\mathrm{d} \\
\text { organizat } \\
\text { ional }\end{array}$ & $\begin{array}{l}\text { Cheng et } \\
\text { al, } \\
2020[17]\end{array}$ & $\begin{array}{l}\text { Regre } \\
\text { ssion } \\
\text { analys } \\
\text { is, SC }\end{array}$ & $\begin{array}{l}\text { POS has a negative regulating effect between } \\
\text { improper customer interaction and EE: high POS } \\
\text { group } \beta=0.12 \text {, compared to low POS group } \beta= \\
0.48, p<0.001\end{array}$ \\
\hline & support & $\begin{array}{l}\text { Wang et } \\
\text { al, } \\
2015[20]\end{array}$ & $\begin{array}{l}\text { Pears } \\
\text { on CC }\end{array}$ & $\begin{array}{l}\text { POS is significantly negatively correlated with } \\
\text { job burnout } r=-0.52, p=0.01\end{array}$ \\
\hline & & $\begin{array}{l}\mathrm{Wu}, \\
2017[25]\end{array}$ & $\mathrm{CC}$ & $\begin{array}{l}\text { POS is negatively correlated with burnout } r=0.39 \text {, } \\
p<0.01\end{array}$ \\
\hline & & $\begin{array}{l}\mathrm{Hu}, \\
2016[23]\end{array}$ & $\begin{array}{l}\text { Pears } \\
\text { on CC }\end{array}$ & $\begin{array}{l}\text { POS is negatively correlated with burnout, } r=- \\
0.41, p<0.01\end{array}$ \\
\hline
\end{tabular}

Abbreviations: NR: Not reported, EE: Emotional Exhaustion, CD: Cynicism/ Depersonalisation, LSA: Low sense of achievement, LPE: Low professional efficacy, OS: Occupational stress, ER: Emotional regulation, ES: Expressive suppression, CR: Cognitive reappraisal, PE: Psychological Empowerment, POS: Perceived organizational support; CC: Correlation Coefficient, SEM: structural equation modelling, CB: covariance based, SPC: Standardized path coefficient, SC: Standardized coefficient

Xiao[21] compared burnout outcome among different socio-demographic groups and reported significant differences between age groups, the 26-33 years old group experienced higher level of burnout compared to the 18-25; the married group experienced higher level of burnout compared to the unmarried; and the $>5000$ (RMB Yuan) monthly income group experienced significantly higher burnout than the $<3000$ group.

\section{DISCUSSION}

This review has described the level of job burnout and associated risk factors among Chinese and Malaysian couriers. The included studies reported moderate to high level of burnout among couriers and certain risk or protective factors associated with burnout. The associations were 
medRxiv preprint doi: https://doi.org/10.1101/2021.11.09.21266103; this version posted November 9,2021 . The copyright holder for this preprint (which was not certified by peer review) is the author/funder, who has granted medRxiv a license to display the preprint in It is made available under a CC-BY-NC-ND 4.0 International license .

established using statistical methods including correlation analysis, regression analysis and structural equation modelling. Factors related to individual psychological process such as emotional regulation could work both ways.

Since all studies used a translated or modified version of MBI to measure burnout, there were significant variations in language, scale and version used. Hence, it was not meaningful to carry out meta-analysis. In addition, as only one paper suggested cut-off points and reported percentages of participants in each category, we were not able to derive the prevalence of burnout. When interpreting the data from the other eight studies, we then arbitrarily applied a simplified standard by considering all scores that is above middle point as an indication of high burnout. This is because that the originally suggested MBI cut-off scores for high burnout were $\geq 27$ in Emotional exhaustion (total 54), $\geq 13$ in Depersonalisation (total 30) and $\leq 21$ in Professional efficacy (total 48) on a 7-point frequency scale 0-6.[26] In addition, a burnout research conducted among nurses in Taiwan aimed to determine the cut-off points of a MBIHSS Chinese version (0-6 scale) also suggested cut-off points for moderate and high burnout at $\leq 21$ and $\leq 32$ for Emotional (total 48), $\leq 23$ and $\leq 30$ for Negative Personal Accomplishment (total 48), and $\leq 6$ and $\leq 12$ for Depersonalization (total 24).[28]

Psychological constructs that are closely related to burnout, such as occupational stress (OS) and turnover intention (TI) were also measured in a number of studies that were not included in our analysis as no burnout measure was reported. They have reported relatively high level of OS and TI among couriers. For example, Wen et al [29] used the Chinese version of Mobley TI scale and reported a mean score of 2.82 on a 1-5 scale. Xu et al [19] used a Chinese TI scale consists of three questions, with the question -- "Looking for other job opportunities" received the highest mean score at 2.775. Xiao [21] defined scores between 12 and 18 as high level of TI and the mean score was 15.27. Multiple standard tools were used to measure occupational stress. Xu et al[19] and Wang et al[20] both used Chinese version Occupational Stress Indicator (OSI) but Xu used the short version with 7 items. Yang[30] and Yang and Mo[31] reported the same study and used the 39 items Enterprise Staff Work Stress Scale (ESWSS). The latter publication reported a mean score of 93.849, indicating a high level of work stress among couriers. One study reported an intervention program that was effective, evaluated by a longitudinal cohort study with one year follow-up.[32] The intervention was an Employee Assistance Program (EAP) that included a range of organizational support, such as stress management training, 7X24 counselling, forums and mini saloons, and a mental health booklet. It significantly lowered TI and OS response in the intervention group.

We found that most of the risk factors reported in the included studies are consistent with the predictors of burnout identified from broader occupational background.[2] However, road safety appears to be a common concern among this population but few studies have analysed it along with burnout. For example a UK study about worker who drive in the gig economy reported $42 \%$ of the participants said they had been involved in a collision and $10 \%$ said that someone had been injured, usually themselves.[10] Conditions could be worse in developing countries. Wang et al[8] conducted 600 observations on busy roads and interviewed 480 couriers in Tianjin, China. They reported that the rate of exceeding speed limit was $91.3 \%$, $21.2 \%$ used cell phone when riding, and reduced use of helmet at night (64.7\% compared to during the day $73.0 \%$ ). $76.5 \%$ of interviewees had been involved in a traffic crash at least once, 
medRxiv preprint doi: https://doi.org/10.1101/2021.11.09.21266103; this version posted November $9,2021$. The copyright holder for this preprint (which was not certified by peer review) is the author/funder, who has granted medRxiv a license to display the preprint in

It is made available under a CC-BY-NC-ND 4.0 International license .

with an average employment time of 17.9 months. Overwork also appears to be serious among Chinese parcel and takeaway couriers.[9, 33] It may be worth considering these factors in future studies about couriers' burnout in certain culture and economic sector where pressure for working hard at fast pace is high.

\section{CONCLUSION}

Based on the findings, we suggest further observational studies are needed to collect higher quality evidence. It is important to develop interventions that offer more organizational support and provide more job resources to couriers. Seven of the nine included studies were published in Chinese, suggesting the importance of including Chinese databases when conducting reviews in relation to couriers. We did not find any burnout studies about couriers conducted in Western country settings. The only relevant study we found was one that researched work stress during COVID-19 pandemic among delivery workers in France and that was assessed using one question.[34] This suggests a significant gap in English literature. We hope this review will provide a useful base for the development of research that aims to reduce job burnout and improve work-related health and safety among couriers in both developing and developed countries.

\section{Acknowledgments}

The authors would like to thank professor Jiangmei Qin and Dr. Yanchun Zhang of China Health Economics Association for their advices that helped refine the aims and objectives of this article.

\section{Contributors}

MvT, HW, CA and TC conceived and designed the project. HW, SGL, TO, MKY and SL conducted reviews in English and Chinese languages and extracted the data. HW and SGL checked the data cross both languages at each steps to maintain consistent standard. HW and TO drafted the manuscript, with CA, TC, PW and MvT contributed to the writing and editing. All remaining authors extensively reviewed and approved the final manuscript.

\section{Funding}

The project is funded by the MRC Public Health Intervention Development Scheme (PHIND). Grant Ref: MR/T027215/1

Disclaimer The funders had no role in the decision to publish or in the preparation of the manuscript. The content is the responsibility of the authors.

Competing interests None declared.

Patient consent for publication Not required.

Ethics approval Not required

Provenance and peer review Not commissioned; externally peer reviewed.

Data availability statement Data are available on request. All data relevant to the study are included in the article or uploaded as supplementary information. Any further data are available on request.

\section{ORCID:}

Hua Wei https://orcid.org/0000-0003-2617-7632

Shugang Li https://orcid.org/0000-0002-9835-4012

Thomas O'Toole https://orcid.org/0000-0001-9830-4229

Christopher J. Armitage https://orcid.org/0000-0003-2365-1765

Tarani Chandola https://orcid.org/0000-0002-1864-3413 
medRxiv preprint doi: https://doi.org/10.1101/2021.11.09.21266103; this version posted November 9, 2021. The copyright holder for this preprint (which was not certified by peer review) is the author/funder, who has granted medRxiv a license to display the preprint in It is made available under a CC-BY-NC-ND 4.0 International license .

Pauline Whelan https://orcid.org/0000-0001-8689-3919

Martie van Tongeren https://orcid.org/0000-0002-1205-1898

\section{References}

1. Demerouti E, Bakker AB, Nachreiner F, et al. The job demands-resources model of burnout: Journal of Applied Psychology. Vol.86(3), 2001, pp. 499-512.; 2001.

2. Shoman Y, El May E, Marca SC, et al. Predictors of Occupational Burnout: A Systematic Review. International Journal of Environmental Research and Public Health. 2021;18(17):9188.

3. Gemine R, Davies GR, Tarrant S, et al. Factors associated with work-related burnout in NHS staff during COVID-19: a cross-sectional mixed methods study. BMJ Open. 2021;11(1):e042591.

4. Rotenstein LS, Torre M, Ramos MA, et al. Prevalence of Burnout Among Physicians: A Systematic Review. JAMA. 2018;320(11):1131-50.

5. Fitzpatrick O, Biesma R, Conroy RM, et al. Prevalence and relationship between burnout and depression in our future doctors: a cross-sectional study in a cohort of preclinical and clinical medical students in Ireland. BMJ Open. 2019;9(4):e023297.

6. Tediosi F, Lönnroth K, Pablos-Méndez A, et al. Build back stronger universal health coverage systems after the COVID-19 pandemic: the need for better governance and linkage with universal social protection. BMJ Global Health. 2020;5(10):e004020.

7. Chan JW-1. Hunger for profit: how food delivery platforms manage couriers in China. Sociologias. 2021;23(57):58-82.

8. Wang Z, Neitzel RL, Zheng W, et al. Road safety situation of electric bike riders: A cross-sectional study in courier and take-out food delivery population. Traffic Injury Prevention. 2021;22(7):564-9.

9. Lin Y 林, Li Y 李. 心理资本、组织支持感在职业紧张与过度劳动关系中的作用一 基于北京地区外卖骑手的调查（The Role of Psychological Capital and Organizational Support in the Relationship between Occupational Stress and Overwork - Based on a Survey of Take-out Riders in Beijing). 中国流通经济 (China Business And Market). 2021;35(4):116-26.

10. Christie N, Ward $\mathrm{H}$. The health and safety risks for people who drive for work in the gig economy. Journal of Transport \& Health. 2019;13:115-27.

11. Glavin P, Schieman S. Dependency and Hardship in the Gig Economy: The Mental Health Consequences of Platform Work. 2021.

12. Freudenberger HJ. Staff Burn-Out. Journal of Social Issues. 1974;30(1):159-65.

13. Schaufeli WB, Greenglass ER. Introduction to special issue on burnout and health. Psychology \& Health. 2001;16(5):501-10.

14. Maslach C. Burned-out. Human Behavior. 1976;5:16-22.

15. Stevens A, Garritty C, Hersi M, et al. Developing PRISMA-RR, a reporting guideline for rapid reviews of primary studies (Protocol). Oxford, UK: EQUATOR Network; 2018.

16. Herzog R, Álvarez-Pasquin MJ, Díaz C, et al. Are healthcare workers' intentions to vaccinate related to their knowledge, beliefs and attitudes? a systematic review. BMC Public Health. 2013;13(1):154.

17. Cheng Z-f, Chen X, editors. A Study on the Influence of Improper Interaction on Couriers' Job Engagement-The Moderating Influence of Organization Support. 2020 4th International Seminar on Education, Management and Social Sciences (ISEMSS 2020); 2020: Atlantis Press.

18. Yoon KH, Lee CY, Peng NL. Burnout and Work Engagement Among Dispatch Workers in Courier Service Organizations. Asia-Pacific Social Science Review. 2021;21(1). 
medRxiv preprint doi: https://doi.org/10.1101/2021.11.09.21266103; this version posted November 9,2021 . The copyright holder for this preprint (which was not certified by peer review) is the author/funder, who has granted medRxiv a license to display the preprint in It is made available under a CC-BY-NC-ND 4.0 International license

19. $\mathrm{XuX}$ 徐, Zhu Y 朱. 外卖送餐员工作压力、职业倦急与离职倾向的关系研究（The relationship between work stress, job burnout and turnover intention among takeaway couriers ）. 全国流通经济 (China Circulation Economy). 2020;2020(23):82-4.

20. Wang F 王, Duan F 段, Kuai X 萠. 快递员工作压力与工作倦急的关系研究 (Research on work stress and job burnout of couriers ). 人力资源管理 (Human Resource Management). 2015;2015(5):300-4.

21. Xiao $\mathrm{H}$ 肖. Analysis on the Correlation between the Psychological Authorization, Turnover Intention and Job Burnout of Couriers in Fujian Province (福建省快递员心理授权 与职业倦急、离职意愿的关联性研究). 医学与社会 (Medicine and Society). 2019;32(12):93-111.

22. Zhao Y 赵. 快递行业员工压力源分析与 EAP 对策研究 (Analysis on stressor of employee of express industry and study on the EAP strategy ) [Master]. Beijing: 中国科学院 (Chinese Academy of Sciences); 2009.

23. $\mathrm{Hu} \mathrm{C}$ 胡. 快递企业员工情绪调节与工作倦急的关系研究 (Exploring The Moderating Effect of Perceived Organizational Support in Emotion Regulation-Job Burnout Relationship). Nanjing: Nanjing University of Posts and Telecommunications; 2016.

24. Zhao Y 赵. A 快递公司一线员工工作倦急因素分析及对策建议 (Factor analysis and policy advices of jobb burnout among frontline workers: study of express delivery company A） [Master]. Yunan: Yunan University of Finance and Economics; 2020.

25. $\mathrm{Wu} \mathrm{Y}$ 吴. 快递企业员工工作压力、组织支持感与工作倦怠的关系研究 (Research on the relationships between work stress, organizational support and job burnout among employees in express delivery companies) [Master]. Nanjing: Nanjing University; 2017.

26. Maslach C, Jackson SE, Leiter MP. Maslach burnout inventory. Third ed: Scarecrow Education; 1997.

27. Li C, Shi $\mathrm{k}$. The influence of distributive justice and procedural justice on job burnout. Acta Psychologica Sinica. 2003;35(05):677-84.

28. Lee H-F, Kuo H-T, Chang C-L, et al. Determining Cutting Points of the Maslach Burnout Inventory for Nurses to Measure Their Level of Burnout Online. History Research. 2017;5(1):1-8.

29. Wen H, Yun Q, Liu D, et al., editors. The Impact of Personality Traits, Group Identification on Courier Turnover Intention: Social Support as a Moderator. 2020 9th International Conference on Industrial Technology and Management (ICITM); 2020 11-13 Feb. 2020.

30. Yang C 杨. 快递员的工作压力、应对方式、主观幸福感的关系 (The Relationships on Work Stress, Coping Style and Subjective Well-being of Couriers). Guilin: Guangxi Normal University 2018.

31. Yang C, Mo W. Work Stress, Coping Style and Three Hierarchic Subjective WellBeing in Couriers: A Structural Equation Model. Psychology and Education Journal. 2021;58(5):1529-38.

32. Li K 李, Tian W 田, Zhao R 赵. 外卖骑手群体的 EAP 方案设计及其干预有效性 (EAP Design for Take-away Riders and Intervention Effectiveness). 心理技术与应用 (Psychology:Techniques and Applications). 2021;9(04):211-8.

33. Lin Y 林, Li X 李, Li Y 李. 北京市快递员过劳现状及其影响因素一基于 1214 名快 递员的调查 (Empirical Research on Employment and Overwork Situation of CouriersBased on the Investigation of 1214 Couriers in Beijing). 中国流通经济 (China Business And Market) . 2018;32(08):79-88.

34. Apouey B, Roulet A, Solal I, et al. Gig Workers during the COVID-19 Crisis in France: Financial Precarity and Mental Well-Being. Journal of Urban Health. 2020. 